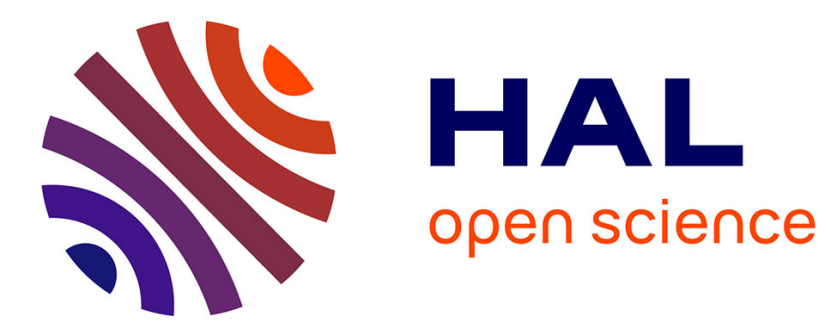

\title{
Animal Scavenging as Social Metaphor: A Carved Chlorite Vessel of the Halil Rud Civilization, Kerman, Iran, Mid Third Millennium bc
}

Massimo Vidale, Nasir Eskandari, Mojgan Shafiee, Irene Caldana, François

Desset

\section{To cite this version:}

Massimo Vidale, Nasir Eskandari, Mojgan Shafiee, Irene Caldana, François Desset. Animal Scavenging as Social Metaphor: A Carved Chlorite Vessel of the Halil Rud Civilization, Kerman, Iran, Mid Third Millennium bc. Cambridge Archaeological Journal, 2021, 31, pp.705 - 722. 10.1017/s0959774321000305 . hal-03471247

\section{HAL Id: hal-03471247 \\ https://hal.science/hal-03471247}

Submitted on 8 Dec 2021

HAL is a multi-disciplinary open access archive for the deposit and dissemination of scientific research documents, whether they are published or not. The documents may come from teaching and research institutions in France or abroad, or from public or private research centers.
L'archive ouverte pluridisciplinaire HAL, est destinée au dépôt et à la diffusion de documents scientifiques de niveau recherche, publiés ou non, émanant des établissements d'enseignement et de recherche français ou étrangers, des laboratoires publics ou privés. 


\title{
Animal Scavenging as Social Metaphor: A Carved Chlorite Vessel of the Halil Rud Civilization, Kerman, Iran, Mid Third Millennium BC
}

\section{Massimo Vidale, Nasir Eskandari ๑, Mojgan Shafiee, Irene Caldana \& Francois Desset}

\begin{abstract}
A fragmentary large chlorite vessel of the Halil Rud valley civilization (Kerman, Iran, mid third millennium $B C$ ), found in unknown circumstances and recently recovered by the police forces of Iran, is discussed in the wider scenario of coeval animal iconographies of middle and southwest Asia. Beginning from the imagery carved in the two superimposed friezes of the reassembled fragments, we review the different theoretical approaches in interpretation of similar animal iconography. The figuration of the vessel is interpreted as a scene of the scavenging of bovine carcasses by three different animal actors: lions and birds of prey/vultures, but also hyenas-a subject previously unknown in the art of the reference regions. Following a review of the interrelations of these species in scavenging and with humans, particularly in the coeval context of domestic animal exploitation and developing urban settlement, we investigate the potential semantic implications of the iconography in terms of the symbolism and ideology in the social context.
\end{abstract}

\section{Introduction}

In January 2020, researchers from the universities of Tehran and Jiroft, members of the Italian Archaeological Mission to South-Eastern Iran (ISMEO), and colleagues of Iran's Cultural Heritage Handicrafts and Tourism Ministry (ICHTM) joined for a three-week documentation project at Jiroft (Kerman, Iran), focused on a collection of about 500 ancient ceramic vessels and more than 100 copper and 100 carved chlorite ${ }^{1}$ artefacts. All these materials had been held illegally by antique dealers and unauthorized excavators and were confiscated by Iranian security forces. None of them were previously published, and they were therefore forwarded to ICHTM for study, prior to entry in the collections of the Jiroft Archaeology Museum.

In spite of the irremediable loss due to illegal, undocumented extraction from archaeological contexts, the collection provides important new knowledge concerning Iran's heritage. These recent acquisitions supplement the masses of material recovered in similar manner and previously published in Iran (Madjidzadeh 2003a; 2007; Piran \& Hesari 2005; Piran \& Madjidzadeh 2013) in revealing the variety and outstanding technical-aesthetic standards of the craftspersons of the long-forgotten civilization of the Halil Rud (Madjidzadeh 2003b).

This article briefly considers some old and new theoretical approaches to the interpretation of prehistoric/protohistoric animal imagery, and then considers the particular case of a new find from the above-mentioned collection: what is left of a large sub-cylindrical vessel of tapering profile, rising to a slightly enlarged mouth (Figs 1-3). The stone is a light green to grey chlorite, relatively soft, of fibrouslaminated structure, with an evident micaceous component. The diameter of the base and mouth 


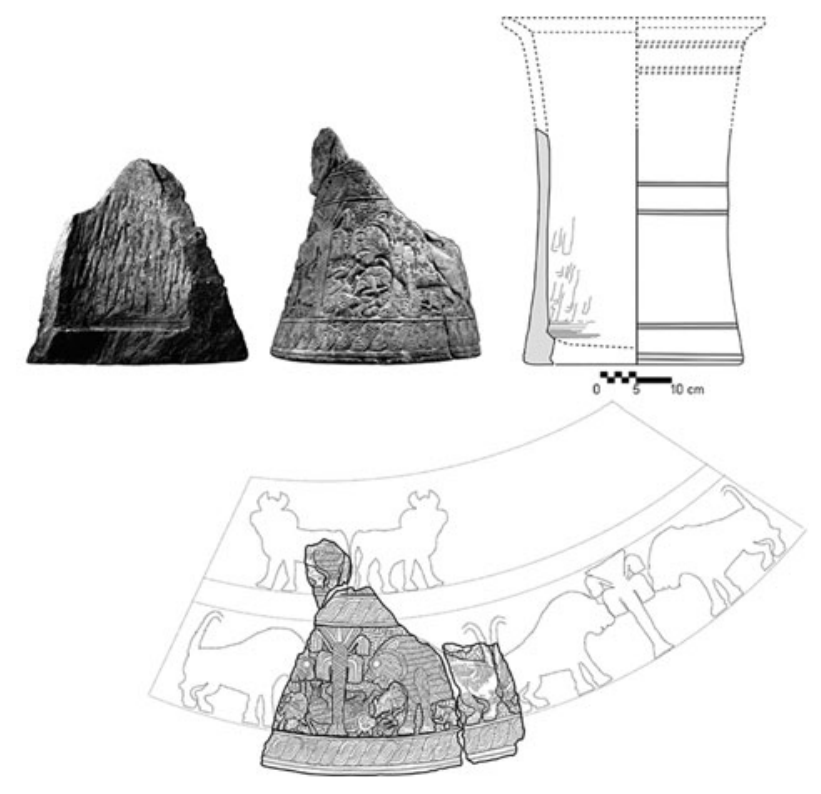

Figure 1. The three fragments of a large chlorite vessel discussed in the paper: photographs and graphic reconstructions of the form and continuous decoration; the complete vase was c. $50 \mathrm{~cm}$ high.

are respectively reconstructed as about 31 and $37 \mathrm{~cm}$, conforming to an original height of $49-50 \mathrm{~cm}$. The three surviving fragments of this vessel do not extend to the upper part; however, this has been conjecturally reconstructed based on the shape and proportions of a stylistically quite similar carved chlorite vessel, also fragmentary, found in the ruins of the Shamash temple at Mari in Syria (Margueron 2004, fig. 274,8$){ }^{2}$ The chronology generally accepted for the chlorite artefacts carved in the Halil Rud style extends from the Early Dynastic II-III through early Akkadian periods (see, among others, Amiet 1986; Aruz 2003; Margueron 2004; Vidale 2015; Wilson 2012).

The stone vessel is remarkable for its size, the intricacy of low-relief patterns, and in particular for its iconography. In the lower register, this features a crowded interaction between not less than four kinds of animals, gathered under a date palmlions, bovines, vultures, and what we shall see are very likely hyenas-in a context of scavenging, while the more fragmentary upper register demonstrates the presence of at least a pair of bovines, in a symmetrical heraldic context.

\section{Some theoretical approaches to animal imagery}

'Archaeological investigation continually confronts us with material contexts that show in no uncertain terms that people in the past classified animals in a myriad of ways different from those of the modern world' (Boyd 2017, 300). Given this, archaeological analysis requires multiple, shifting classifications, converging from different viewpoints (Serjeantson 2000). Animal symbolism (Ryan \& Crabtree 2015) may be considered as a widespread form of animal exploitation, largely inspired, of course, by banal anthropocentric concerns. In this regard, Boyd $(2017,302)$ argues that, until two decades ago,

there was a feeling that anthropocentrism was not really an epistemic problem for anthropology because its fundamental object of study is/was the human. Nonhuman animals were of interest to cultural anthropologists insofar as they were instrumental to spheres of human practice such as rituals, as perceived components of human cosmologies, as symbols, etc.

At present, in contrast, there is a trend in anthropology to consider animals not simply as dependent objects, but rather as complex causative agents, encouraged by the fact that in the wider and crucial spheres of Anthropocene geopolitics and planetary ecology, human-non-human animal relationships are now core issues of discussion. Admittedly, when dealing with semantic systems extinguished 4000 years ago, any claim of confidently dismissing anthropocentrism on the part of the human actors would be unrealistic, and also of little use. And any post-processual social zooarchaeology (i.e. the investigation of the archaeological record from the viewpoint of the reflexive relationship between ideas on the animal worlds and social strategies), animal agency issue, or relativistic zoontology would risk remaining as anthropocentric as the most deterministic research based on statistics concerning prehistoric exploitation of animals for meat.

The current case study suggests, however, that in early complex societies, the conception and representation of animals was not limited to simplistic anthropocentric views. The Halil Rud carved artefacts, in fact, show many complex scenes of wild animals scavenging the carcasses of domestic ones. Here, neither the scavenger nor carcasses of animals are depicted as sources of human food, since both of these were and still are despised for such purposes. Nor are they shown as static icons, conveying the usual prestige implications. Instead, the image of the scavenger is that of an agent species, and it could be true that for us, who care to study such iconography,

the interaction between different species links us back to the pre-postmodern moment in anthropology, when animals and plants were central elements of ethnographic research, when cattle, coral gardens, rice cultivation, 


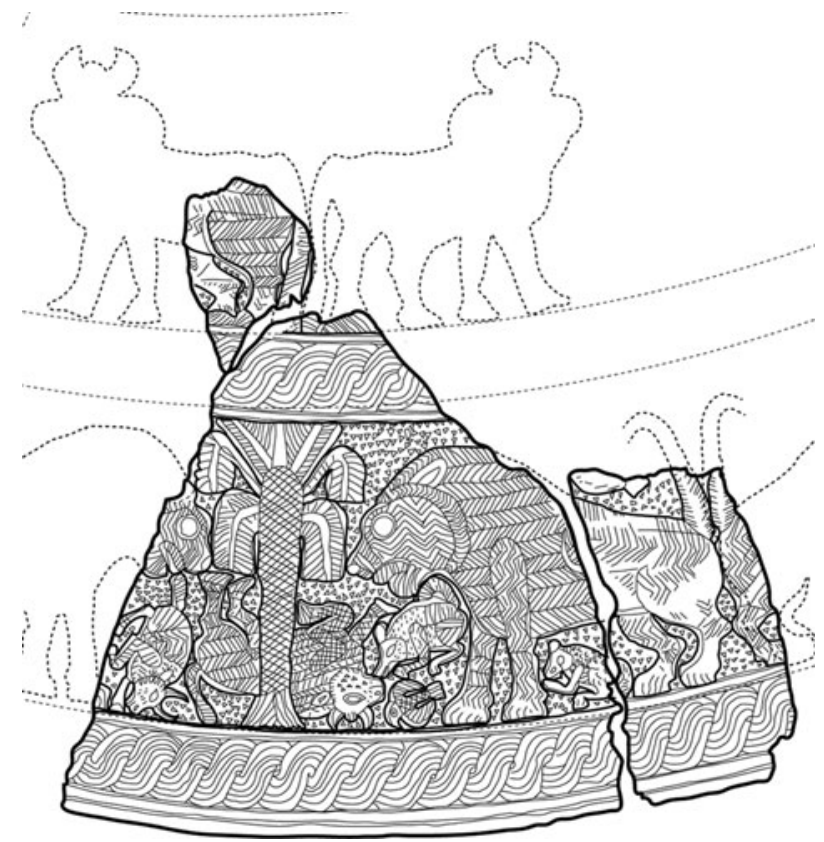

Figure 2. Graphic rendering of the recomposed carved surface, detail.

and so on were thoroughly embedded and attended to in almost every major anthropological monograph. (Smart 2014, 4)

Perhaps this pre-postmodern perspective could help us understand the social dynamics of an early Bronze age polity, from which we have as yet no readable texts. What were the effects of these images in the cognitive and psychological processes of the intended viewers, embedded in urban elites? The aim of this study is, then, to investigate the potential meanings behind such a distinctive set of iconographic choices, recurring in the repertory of the most important early Bronze age cultural complex of southeastern Iran, but completely unknown in other contemporary civilizations (see this and similar issues posited in McMahon 2016, 178).

\section{Description of the imagery}

None of the animal protagonists of the subject Jiroft vessel have any evident sexual characterization, suggesting that rather than being of interest for their individual sexual roles, they may have been viewed as interacting species. On the other hand, the representation of these bovine, feline and other creatures leaves open the possibility that they could all be female. The uncertainty is intriguing: our current research, in fact, has documented instances where the Halil Rud sculptors clearly took pains to

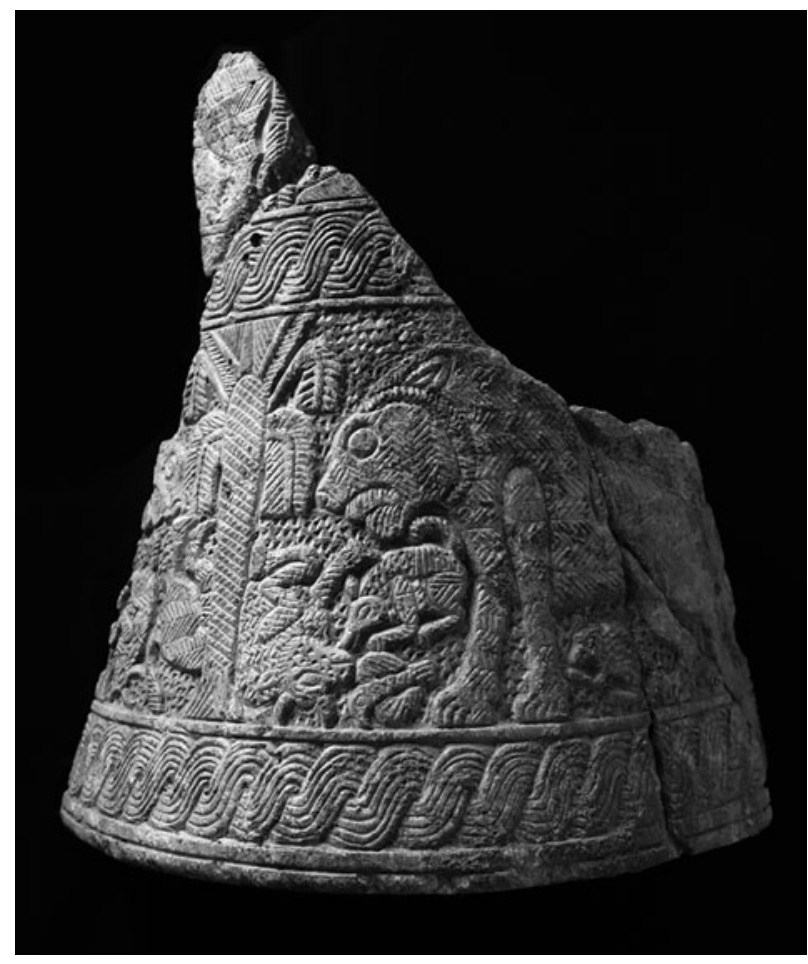

Figure 3. The three re-fitted shards.

represent male and female specimens, particularly when showing herds or groups. Other considerations are that animals are often shown on chlorite in crouched position, negating the distinction of sex; lions are very rarely shown with male organs (the presence or absence of a mane is not indicative, given that male Asiatic lions lack the full mane of their African cousins); cheetahs/leopards are never portrayed with sexual attributes; bulls may be shown with large organs, but mostly when in prominent positions and while emitting powerful water flows, which might suggest their powers of fertility. Animal carcasses are never shown with penises. Given these considerations, in our own following discussion we intentionally use 'lions', 'bovines' and other animal names without suggestion of sex.

The larger fragment of the subject vessel shows the forequarters of a large lion and the head with open jaws (Fig. 4). The entire forequarters are covered with horizontal bands of alternating oblique segments, while the legs and the muzzle bear zig-zag lines. The head, seen in profile, is animated by a large round eye, pointed ear and a narrow crescent indicating the mane. The lion stands facing a palm with four bunches of dates; behind the trunk of the palm is a bovine lying supine with upturned legs-apparently dead (Fig. 5). 


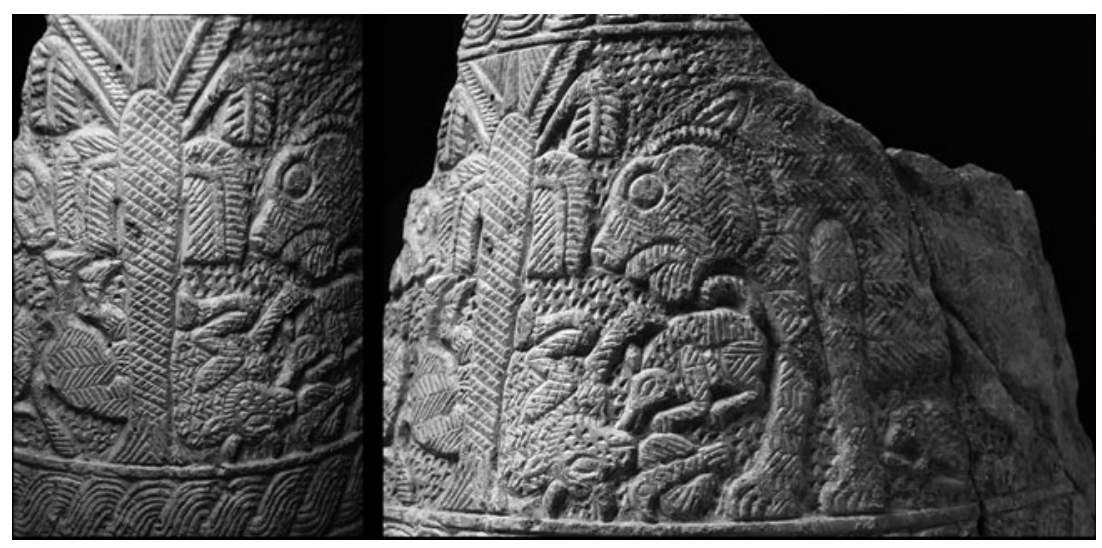

Figures 4 \& 5. (4, right) The central part of the fragmentary vase: lion attacking or scavenging a dead bovine, accompanied by other animals; (5, left) Left side of the fragmentary vase: detail of a second dead bovine under a date-palm.

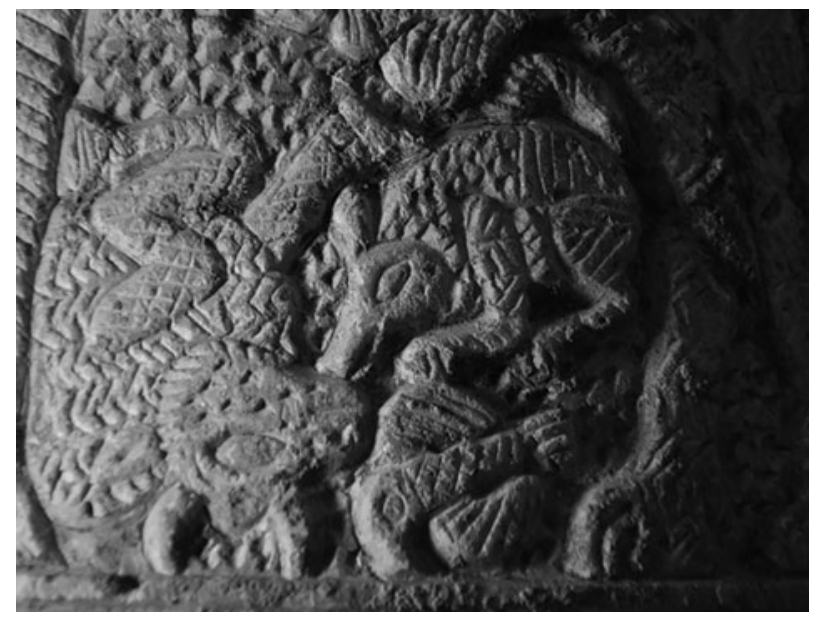

Figure 6. Detail of a carnivore, identified as a hyena (see text), scavenging the larger dead bovine.

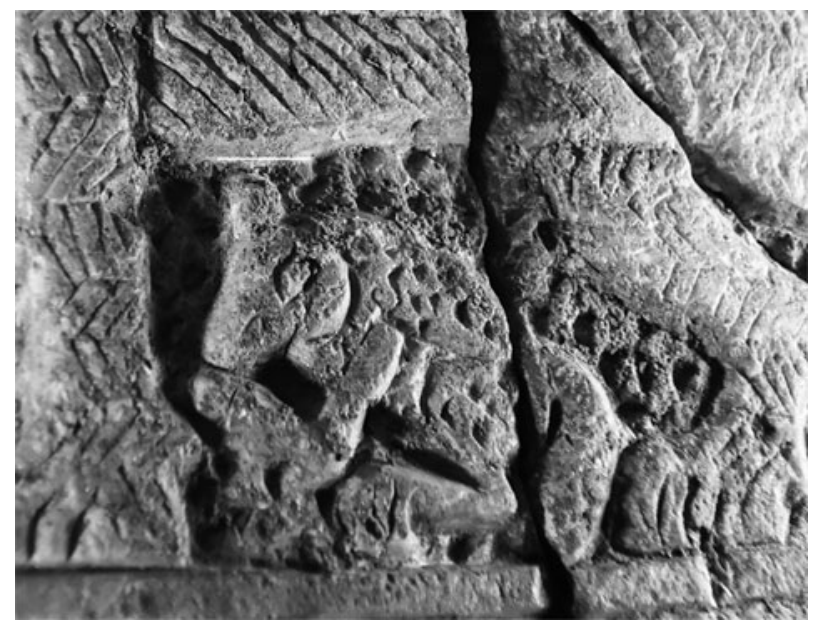

Figure 7. Detail of a smaller animal under the belly of the lion, possibly a hyena cub(?).

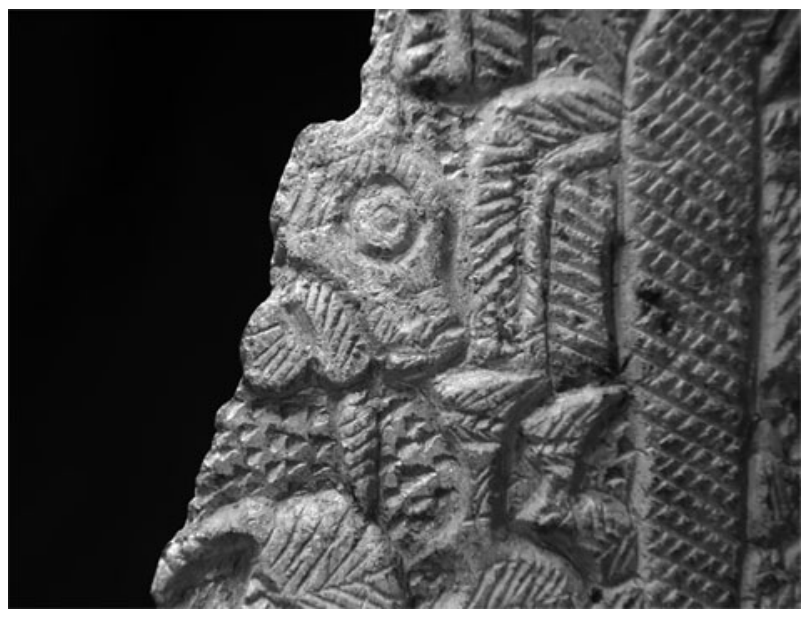

Figure 8. Detail of the head of a second lion in symmetric setting beside the palm. The mouth bites the tail of a second upturned bovine.

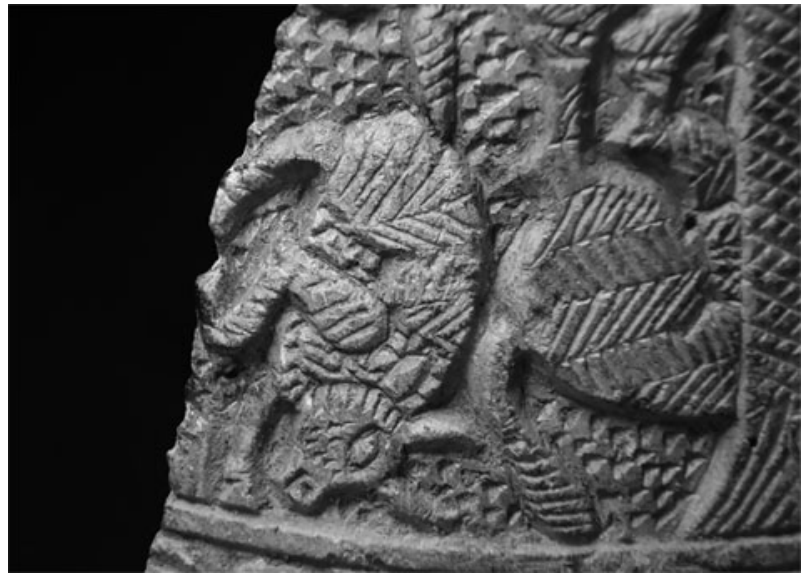

Figure 9. Detail of the second smaller upturned bovine, attacked by the second lion. 
The space between the feline and its prey is occupied by a smaller carnivore which crouches to bite the throat of the bovine, and which, as we shall soon demonstrate, can be identified as a hyena (Fig. 6). Another similar creature, still smaller, appears in a similar position between the legs of the lion (Fig. 7). Although the poorer preservation of this smaller carved figure hinders identification, this could be a cub of the same carnivore species. A small raptor, wings tucked in diving position, arrives below the larger carnivore, very near the head of the dead bovine (Fig. 6, bottom). Of another raptor, carved above the back of the feline, only the tail and parts of a wing survive. On the side of the palm opposite the first lion/lioness, there appears the head of another (Fig. 8), at the same height as the first, which seems to bite the tail of a smaller bovine, shown in the peculiar position of a headstand (Fig. 9).

A smaller fragment completes the body of the first lion, adding part of an erect tail, and shows enough of the rear quarters and tail of another animal to conclude that the frieze probably continued with another symmetrical lion. The third and uppermost shard (Figs $2 \& 10$ ) shows that the upper frieze, now lost, featured one or more couples of undisturbed bovines in a heraldic posture, perhaps as a prequel to the events below.

There are no coloured inlays, and the background of all fragments is densely filled by dots worked with a pointed tool. ${ }^{3}$ The lower frieze clearly represents a scene of three kinds of animals engaged in the killing of bovines or scavenging of their carcasses. While the dimensions of the prey would rule out any other actor as the authors of the kill, it is impossible to understand if the lions are indeed responsible, or just opportunistic actors.

Previous studies have not provided specific comment on images of this kind, even though our survey has found publication of at least 14 different chlorite artefacts (Table 1) dealing in similar subject matter. The rest of this paper discusses the zoological identities and possible symbolism of the actors involved in the scenes of this particular vessel.

\section{Techniques of execution}

The surfaces of the vessel fragments bear evidence of the techniques of fabrication. The interior remains rough, which is a unique case among vessels of the Halil Rud corpus. From this observation, and considering the relatively thin vessel walls, it would appear the vessel broke before the stage of finishing the interior. Observation by the naked eye reveals the use of different specialized tools. The interior

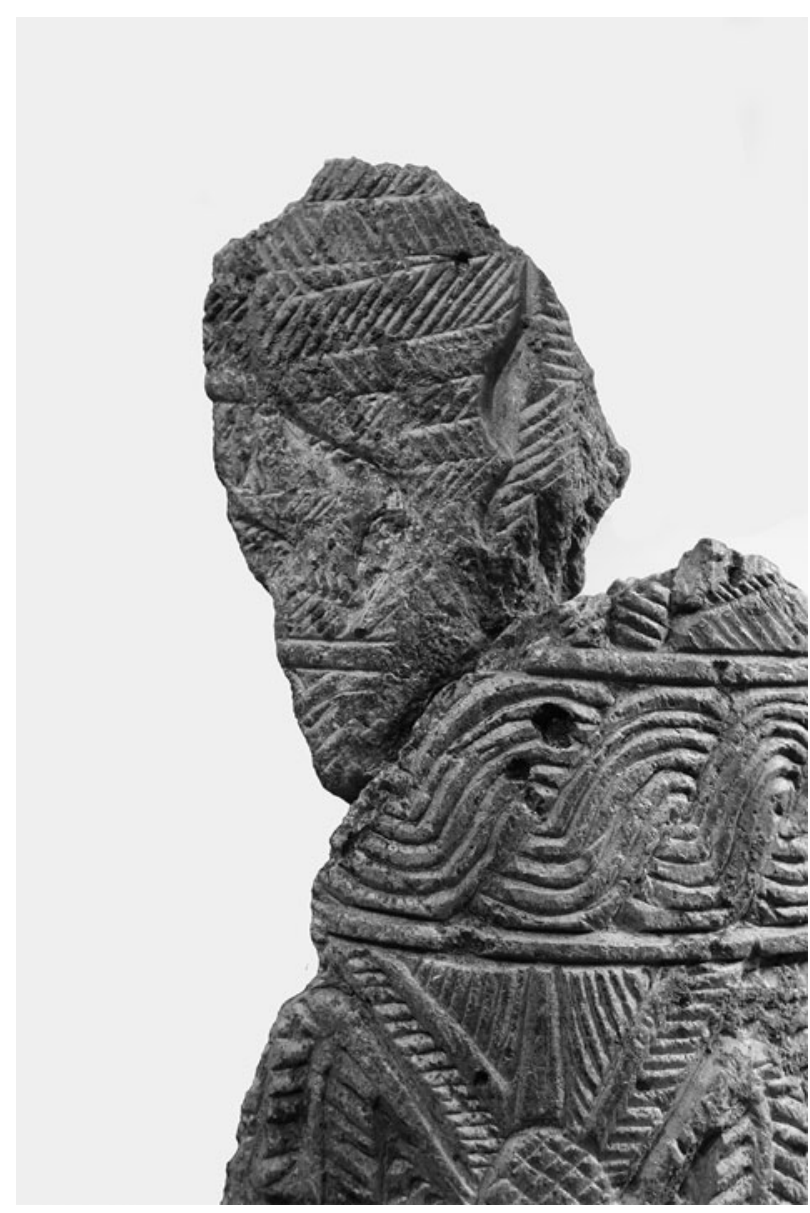

Figure 10. The third fragment, joined at the upper left corner, indicates the presence of two other bulls, probably in symmetric/heraldic position (as reconstructed in Figure 2).

(Fig. 11) retains a dense tracery of shallow gouges left by a relatively large chisel, slanted both laterally and into the thickness of the stone as the work proceeded. The inner bottom edges of the fragments show signs of a rotating device, probably left by a gouge operated by hand in a rotating motion (Fig. 12). The outer surfaces show traces of work using different tools: a fine-bladed flat chisel (e.g. for textured detailing of the lion's head: Fig. 8); a pointed tool, used to remove triangular chips from backgrounds and other areas (e.g. surrounding the lion's head: Fig. 8); and most likely another chisel with a curved blade (e.g. for the mouth and possibly brow/muzzle of the same lion's head).

The artisanal equipment for the final stages of execution of this particular piece therefore included not less than five different tools. Neither our own research nor the bibliographic sources have provided other exemplars of chlorite works with the pecked 
Table 1. A list of all known animal scavenging scenes on carved chlorite vessels of the Halil Rud tradition, with bibliographic references. NI: not identified.

\begin{tabular}{|c|c|c|c|c|c|c|}
\hline Item ID & Location & Provenance & Description & Bibliography & Killer/scavenger & Scavenged \\
\hline 128887 & British Museum & $\begin{array}{l}\text { Khafajja, } \\
\text { Diyala Valley, } \\
\text { Iraq }\end{array}$ & cylindrical vessel & Aruz 2003a, n. 227, 330-32 & raptor, lion & zebu \\
\hline NI & NI & Jiroft area & cylindrical vessel & Madjidzadeh 2003a, 101-2 & snakes & bovine head \\
\hline NI & NI & Jiroft area & fragment of flask & Madjidzadeh 2003a, 91 & large cat (leopard) and snake, in combat & ram \\
\hline NI & $\mathrm{NI}$ & Jiroft area & cylindrical vessel & Madjidzadeh 2003a, 64 & lion and raptor & $\begin{array}{l}\text { bovine } \\
\text { (species NI) }\end{array}$ \\
\hline NI & NI & Jiroft area & flask & Madjidzadeh 2003a, 60-61 & raptor (vulture) & ram \\
\hline NI & NI & Jiroft area & flask & Madjidzadeh 2003a, 40-41 & lions & $\begin{array}{l}\text { bovine } \\
\text { (no hump) }\end{array}$ \\
\hline NI & NI & Jiroft area & flask & Madjidzadeh 2003a, 38-9 & lion, raptor & $\begin{array}{l}\text { bovine } \\
\text { (species NI) }\end{array}$ \\
\hline NI & $\begin{array}{l}\text { National Museum } \\
\text { Tehran }\end{array}$ & Jiroft area & handled weight $^{\mathrm{a}}$ & Piran \& Hesari 2005, 51 & lions, raptors, foxes or jackals & $\begin{array}{l}\text { bovine } \\
\text { (species NI) }\end{array}$ \\
\hline NI & ICHHTO, Jiroft & Jiroft area & cylindrical vessel & $\begin{array}{l}\text { unpublished, research by current } \\
\text { authors }\end{array}$ & lion, raptor, fox & $\begin{array}{l}\text { skeletonized zebu } \\
(?)\end{array}$ \\
\hline NI & $\begin{array}{l}\text { National Museum } \\
\text { Tehran }\end{array}$ & Jiroft area & flask & Piran \& Madjidzadeh 2013, 108-9 & lions, raptor & $\begin{array}{l}\text { bovine } \\
\text { (no hump) }\end{array}$ \\
\hline NI & $\begin{array}{l}\text { National Museum } \\
\text { Tehran }\end{array}$ & Jiroft area & handled weight & Piran \& Madjidzadeh 2013, 67 & lions & $\begin{array}{l}\text { ungulate } \\
\text { (species NI) }\end{array}$ \\
\hline \multirow{2}{*}{ NI } & \multirow{2}{*}{ White-Levy Collection } & \multirow{2}{*}{ NI } & \multirow{2}{*}{ handled weight ${ }^{\mathrm{b}}$} & \multirow{2}{*}{ Pittman 1990, 42, no. 28 , fig. 8} & face 1: lions & $\begin{array}{l}\text { bovine } \\
\text { (no hump) }\end{array}$ \\
\hline & & & & & $\begin{array}{l}\text { face 2: leopards or cheetahs, fox or } \\
\text { jackal, raptors }\end{array}$ & ram \\
\hline $\begin{array}{l}\text { TH } \\
01-960-\mathrm{Dz}\end{array}$ & Deir ez-Zor Museum & $\begin{array}{l}\text { Temple of } \\
\text { Ninhursag, } \\
\text { Mari, Syria }\end{array}$ & $\begin{array}{l}\text { sub-cylindrical } \\
\text { vessel }\end{array}$ & $\begin{array}{l}\text { Margueron 2004, } \\
\text { Fig. 274, } 4\end{array}$ & feline (?), fox or jackal (?) & $\begin{array}{l}\text { bovine? } \\
\text { (species NI) }\end{array}$ \\
\hline
\end{tabular}

a A modern forgery, according to Muscarella $(1993,151)$, but we question this opinion.

b Also considered a modern forgery by Muscarella $(1993,151)$ and, again, we disagree. 


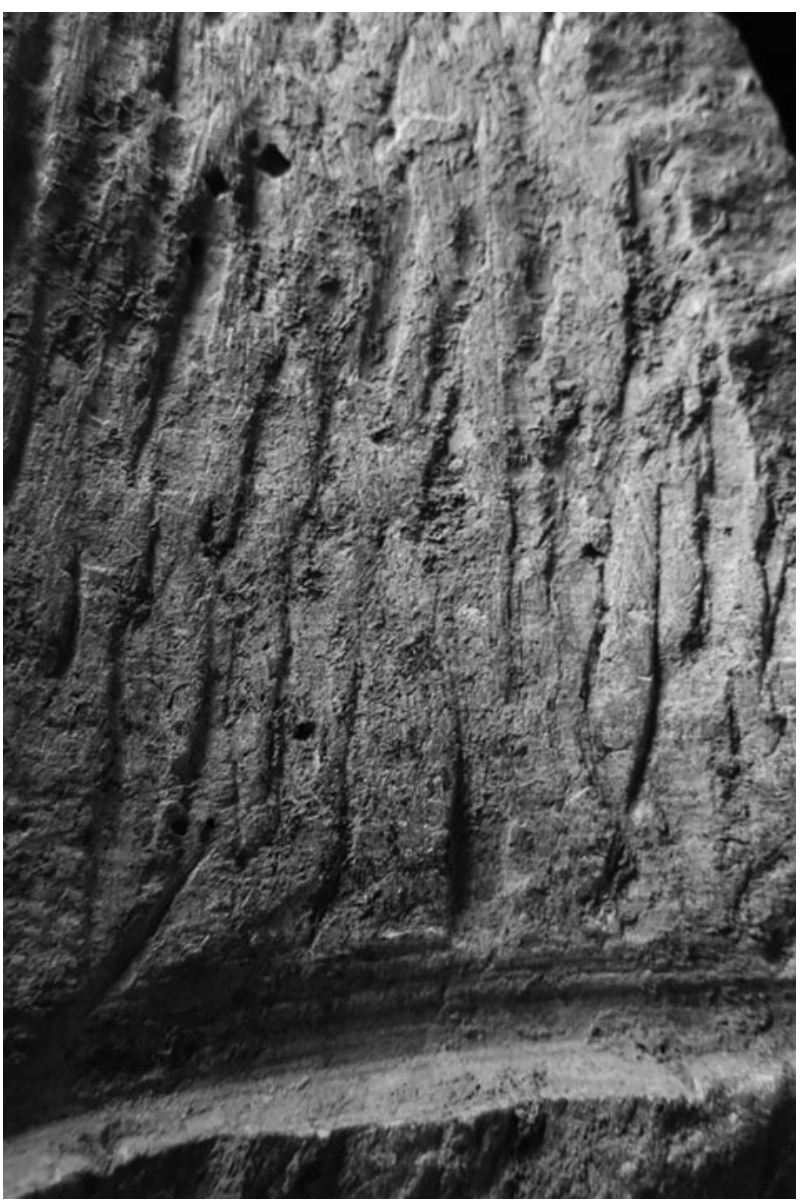

Figure 11. Detail of the rough interior of the fragmented vessel.

background seen in these fragments. This, with the scarce polishing of the outer surfaces, strengthens the supposition of a failure towards the final stages of execution. In view of the lack of the pecked effect on other known pieces, it seems probable that the next stages of the work would have involved lowering and finely polishing these areas, and further finishing of the interior, perhaps by operators of different skill levels, but that a breakage caused abandonment before these steps could be executed. All these observations and assumptions would imply a wellendowed workshop, operating with more than the five tools used in these early steps of execution, and possibly with two or more levels of skilled artisans.

\section{Previous interpretations of the Halil Rud chlorite artefact imagery}

Although there has been great interest in southeastern Iranian carved chlorite artefacts over the past 50 years, ${ }^{4}$ there have been few attempts at

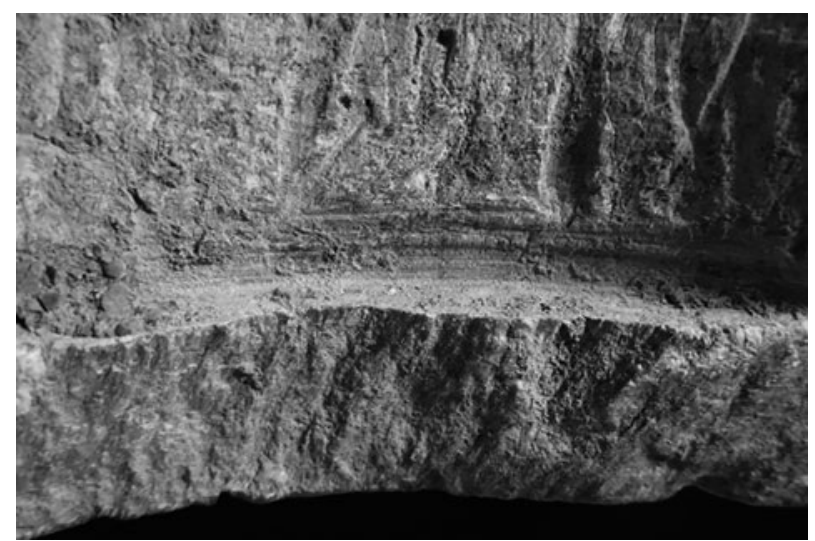

Figure 12. Detail of the rough interior of the fragmented vessel: trace left by a large rotating gouge.

interpreting their abundant iconographic content in any kind of coherent framework. Until recently, the paradigm conception of the 'intercultural style' vessels had directed research and iconographic interpretation towards only the most generic and readily apparent readings, potentially shared by the different cultures across all the regions of distribution, rather than seeking their significance with respect to the social contexts of origin.

D. Potts (1978) searched for religious inspirations in the chlorite artefacts, stressing that that scholars should not be 'mesmerised' by the sole interests of production and exchange (D. Potts 1978, 481-2). He considered the possibility that some of the carved signs and representations could be 'divine emblems' of different Mesopotamian divinities, such as rosettes or solar signs, associated with the sun-god Utu; the ibex with Enki; dogs with Nininsina; while the lion-headed bird would be associated with Ningirsu-Ninurta.

C.C. Lamberg-Karlovsky (1988) attempted the first holistic quantitative analysis, by means of counts of the motifs recognized at the time and their associations with one another and the different object types. The analyses suggested the existence of two main 'iconographic clusters': the hut or temple-façade motif (door with a curved lintel) and snakes in combat. He proposed that the repertory of images was associated with beliefs and behaviours involving death and burial. The analyses did not mention the iconography of predator/scavenger scenes.

S. Winkelmann applied a similar analytical approach. Intuitively, she identified 17 basic iconographic associations, among them: eagle on a tree; lions/snakes flanking a tree; feline/snake attacking hoofed animal; bird of prey landing on hoofed animal. She then argued that the 'hoofed animal with bird of prey' would be the narrative embryo of a 
broader story of the 'hoofed animal killed by a lion with diving bird of prey', or more specifically a 'diving vulture' (Winkelmann 2005, 187), and reasoning rather freely that all 17 associations would pertain to a single 'intercultural myth' shared from Mesopotamia to Iran and South Central Asia, eventually emerging in written form as the celebrated Old Babylonian myth of Etana (Hess \& Streck 2009; Kinnier Wilson 1985).

Perrot and Madjidzadeh (2005; 2006) proposed that single elements of the Jiroft iconographic repertoire composed an overall semantic system, and that each would have certain associations, with some being inspired by aspects of the local environment (mountains, water), another representing a 'transcendental portal', and others serving as totemic symbols.

The representations of the various animals would be expressions of their qualities in a cultural view, in terms either of positive forces (e.g. zebu = strength; ibex =agility; lion = regal) or negative ones, represented by creatures such as snakes, scorpions and a small scavenging raptor (Perrot \& Madjidzadeh 2005, 144). The entire semantic system would have served in a funerary context. Surveying this entire system, the same authors remarked that although one can propose various interpretations of the images, their deepest meanings would remain elusive (Perrot \& Madjidzadeh 2006, 108). Still, their sense was that the semantic core of the Jiroft iconography was the search of a human order over nature (Perrot \& Madjidzadeh 2005, 146), or the generic contrast between life and death, culture and nature. Finally, this opposition would have been the basis for the later dualism of Iranian religions.

More recently, H.-P. Francfort (2020) recognized a less systemic iconography of 'elementary life and death cycles', featuring lethal predators (felines, scorpions, raptors) composed in 'groups of death', who kill and/or feed on ungulates turned upside down, with the scavenger birds being vultures. ${ }^{5}$ The 'groups of life' are instead composed of a being of human appearance, kneeling or seating on a zebu and holding flows of water, associated with sun and crescent-moon emblems and often trees. ${ }^{6}$ The deeper meanings of this fundamental opposition are not further explored.

M. Vidale $(2015 ; 2017)$, one of the present authors, has previously tried to relate the potential significance of the hut or temple-façade motif, the probable motif of a rainbow, and some specific depictions of multiple actors, to parts of an archaic Iranian version of the flood myth (see Lambert 1965; Lambert \& Millard 1969), an association that could also account for the presence, on many chlorite objects, of palm trees loaded with bunches of dates. Moreover, similarly to Winkelmann, Vidale (2015) recognizes a part of the Etana myth, in which the eagle hides in a carcass in search of revenge on the snake, as originating in one or more Iranian narratives involving scavenging animals.

\section{The vessel: discussion of the animal imagery}

\section{Bovines}

The smaller bovine, at the left of the main fragment, is sculpted with a plump body incised with an irregular patchwork of lines. As previously noted, the up-ended orientation of the body and the attitude of the lion above clearly communicate that the ani$\mathrm{mal}$ is either carcass or prey. The features are insufficient to suggest whether this small bovine, with horns but no hump, could be a juvenile of the larger one or a separate species.

The larger animal, behind the palm tree, is sculpted with one of its legs crumpled, probably communicating a violent death. The body is covered by horizontal bands of diagonal lines, similar to those incised on the felines, but the legs are crosshatched. Although the detail of the back is interrupted by the palm trunk, the contour immediately to the rear of the head suggests a hump, probably communicating that this is a Bos indicus, the Indian zebu, a frequent subject in chlorite iconography. Of the 13 dead upturned animals observed on other chlorite artefacts (Table 1), nine are bovines, but often the depiction is limited to the severed head, prohibiting identification of species. Two are depicted with humps, similarly confirming the identification of Bos indicus.

In view of the chlorite iconography, Perrot and Madjidzadeh $(2006,104)$ had proposed that the residents of the Halil Rud basin and highlands of the third millennium BC would have shared these territories with populations of wild zebus, but recent genetic studies (Chen et al. 2010) indicate that this was quite unlikely. The evidence is that in the Indus valley, the wild South Asian auroch, Bos primigenius namadicus, had instead already given way to herds of domestic Bos indicus between 6000 and $5000 \mathrm{bp}$. From here, domestic herding then progressively displaced the wild populations through Baluchistan and Makran, ensuring ample time for occupation of the Halil valley well before the third millennium BC.

\section{Lions}

The body of the right-hand big cat rises in dynamic lines from the rear haunches, in low relief covered 
completely in bands of diagonal lines, arriving at the ruff and details of nose and mouth, which frame a large, dilated eye (Fig. 4). The almost hypnotic total effect achieved by this technique is still present in the second cat, even though surviving only as the eye and part of the head. The short, thin mane of the lion leaves the ear in full sight, as is typical of southwest Asian populations. The recurved erect tail, in contrast, is a non-realistic detail seen frequently in the work of the Halil Rud stone carvers, possibly as a space-filling expedient (Perrot \& Madjidzadeh 2005).

The subspecies of the Asiatic/South Asian lion (Panthera leo persica) colonized these regions sometime between 100,000 bP and 20,000 bp (Kitchener et al. 2017, 72-3; Nowell \& Jackson 1996, 37). As late as the nineteenth century these felines could still be found from Iraq to eastern India and as far north as Greece; however, the last occurrence in Iran dates to 1942, and the subspecies now survives only in Gir National Wildlife Sanctuary, Gujarat, India.

In the first half of the twentieth century, Pocock $(1939,222)$ reported the Gujarat lions feeding on wild buffaloes, but equally on livestock attacked in the night, near farms. In 1996, Nowell and Jackson estimated that herders were bringing up to 20,000 head of cattle into the sanctuary during peak season, and that these were now the lions' primary source of both kills and carcasses. The ecology of the Halil Rud environment in the third millennium $\mathrm{BC}$ is not yet fully known; however, the identification of at least some of the bovines of subject vessel and the bibliographic reports convey a certain frequency of attacks on domestic animals, and thus the coexistence of man and beast in a substantially anthropized environment.

A. McMahon (2016, 178) poignantly portrays the almost universal human perceptions of the lion: 'They move smoothly and beautifully, they are efficient and powerful hunters, their roar is frightening but thrilling, they inspire fear, respect and awe.' McMahon $(2009,111)$ also makes clear, however, that there can be contrasting iconographic meanings: 'Lions are paradoxically the equal and the opposite of kings; they are the only creatures powerful enough to be considered worthy opponents of kings, yet they are wild and vicious as contrasted with the kings' reliable strength, protective abilities and place in civilization.'

\section{Hyenas}

The second carnivore species, with pointed muzzle and upraised ears, such as potentially to represent some kind of canid, can be much better understood as a member of the Hyaenidae family, neither dog nor cat (AbiSaid \& Dloniak 2015), and specifically as the Asian striped hyena. The foxes and jackals of the Canidae can be excluded, since the current convention is that these are depicted on the Halil valley works with much more slender form and gracile posture (e.g. Fig. $13 \mathrm{a}, \mathrm{b}){ }^{7}$ The other convincing factor is the aggressively hunched posture of the carnivores on the subject vessel, particularly for the one on the left (Fig. 6), which compares extremely well with the typical posture, features and even colouration of the Asian striped hyena (compare Fig. 13 c \& d): robust body, substantially larger than the head; large erect ears, furry tail; stripes on the legs, haunches and abdomen.

The detail of the almond-shaped eye seems potentially anomalous, since in the known art of the chlorite objects, carnivores are always observed with large round eyes, while the herbivores are shown with the almond shape. However, hyenas, like foxes and jackals, will also willingly eat fruit and vegetables, meaning they are omnivorous carnivores, whereas the lion and raptors, both shown with the round eyes, are exclusively carnivorous.

Although the striped hyena is native to a very wide range, from North Africa to the Caucasus and the Indian subcontinent, their nocturnal habits and current low population densities have contributed to making them the least studied of the Hyaenidae. This species, smaller than the brown and spotted hyenas, survives nowadays in peripheral regions of Israel and the Middle East, Afghanistan, Baluchistan, southern Punjab, Cholistan and Sindh (Frembgen 1998). Known as kaftär in Persian, it was still common in Iran through the nineteenth century, and sighted as late as 1933 near large cities like Tehran. It is now rare in the north but remains relatively more common along the Persian Gulf (Anderson 2012). According to Monchot and Mashkour (2010), it may still be encountered in marginal niches of the Halil valley. In spite of the anthropization of the entire Iranian region, there are no reports of attacks on humans.

In Africa, striped hyenas scavenge the carcasses of large and medium-sized ungulates, including zebras, gazelles and impalas, and also eat fruit, insects, birds, hares, rodents and reptiles (Howard 1999). At present, in the Gir Wildlife Sanctuary of Gujarat, 'the availability of safe refuge, with human and livestock presence (alternative food from carcasses by natural causes and by predators) may govern their population' (Shamshad Alam et al. 2015, 37). A study specifically on the current feeding habits of striped hyenas in Kutch, Gujarat (Bopanna 2013), finds that in the moderately anthropized rural environment hyenas are opportunistic predators and 

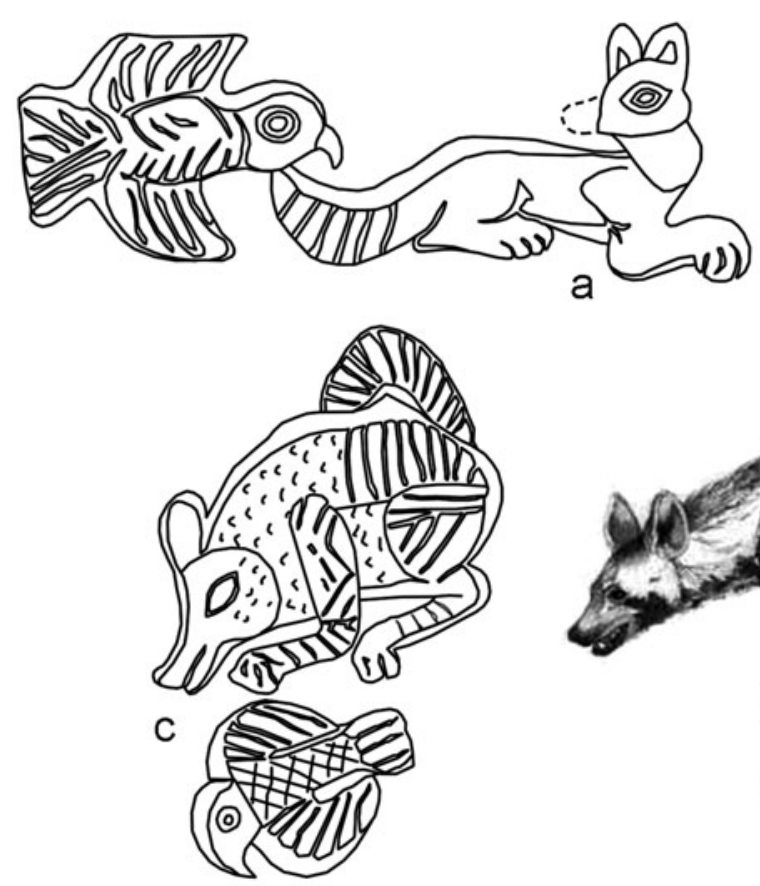
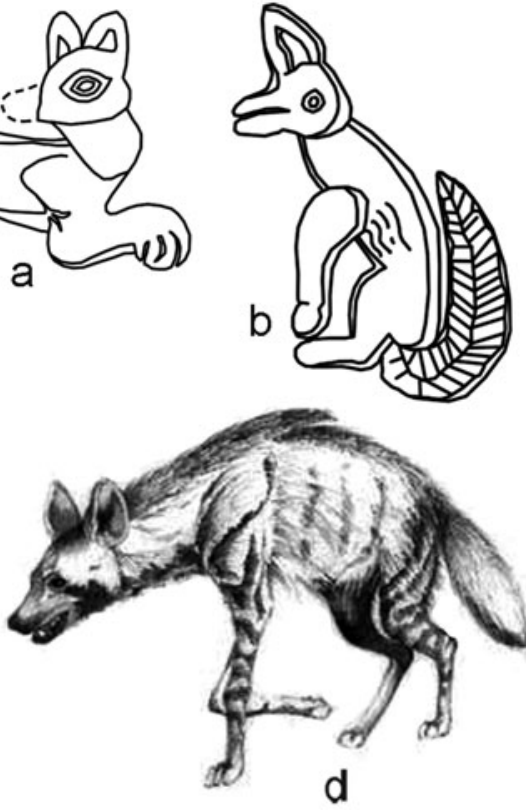

Figure 13. $(a, b)$ Wild canids portrayed on other chlorite vessels ( $a$, accompanied by a small raptor, from an unpublished vessel of the Jiroft Museum collection; $b$, from Piran \& Hesari 2005, 51); (c) The carnivore on the fragmentary vessel discussed in this article, also accompanied by a small raptor. The carnivore may be compared with the striped hyena illustrated in (d) (from Habibi 2004, 67): note the close similarity of muzzle and ears, and particularly of the stripes on the legs and on the rear, while the forepart of the fur is almost blank. scavengers. Here, more than 50 per cent of their diet consists of vertebrate meat, of which the carcasses of domestic cattle, goats and sheep comprise the main part, followed by those of dogs and jackals. The remaining diet of this population consists of a wide range of vertebrate and invertebrate prey and vegetal foods (Bopanna 2013, 95). Monchot and Mashkour $(2010,17)$ add that 'their behavioral adaptations are directly connected to modifications in their environment, such that it may be considered as a commensal animal associated with human activities'.

Habibi $(2004,68)$ reports that in recent decades, 'Hyenas are trapped by professional hunters in Kandahar, from their dens and forced to fight dogs, with tails tied to a pole or peg. However, they are released after being kept in captivity for a short period of time.' Similar practices are reported across western and southern Asia, where striped hyenas are generally considered as creatures of the night, incarnations of jiins, vehicle of wizards and witches, and mystically powerful creatures. All bodily parts, but in particular the sexual organs and excrements, are ingredients of a variety of practices connected with love magic, sexuality, fertility and warding off evil (Frembgen 1998).

\section{Vultures}

In general, the anatomical rendering of the raptors on chlorite artworks is highly stylized, lacking indicators for distinction at the level of species, which might include any of the hawks, eagles, kites, or at least nine species of griffons and vultures endemic to the Iranian Plateau.

The only exception is the 'beard' of the vulture Gypaetus barbatus, in reality the tuft of feathers that falls over the beak in adult individuals: ${ }^{8}$ this detail is easily recognizable on a number of carved chlorite artworks. A study by Margalida et al. (2009) on the diet of the bearded vulture in the Spanish Pyrenees showed that it was based on mammals (93 per cent), among which medium-sized ungulates (mainly sheep/goats) were most important (61 per cent of mammal remains). Surveys on Gypaetus barbatus and three other species of vultures in the Caucasus of Azerbaijan (Karimov and Guliyev 2017) showed that while the others fed on a variable range of domesticated and wild animals, bearded vultures ate the carcasses of the Dagestan tur Capra cylindricornis in 44-53 per cent of cases. Some of the carcasses were from dead kids, others from the kills of grey wolves or of trophy hunters, who left the unwanted bodies. In short, bearded vultures are strongly oriented to scavenging the carcasses of capriovines, a behaviour reflected in the scenes of the Halil Rud artefacts where birds of prey dive on carcasses of sheep or goats (Table 1).

The vultures' feeding habits, in any case, like those of striped hyenas, appear deeply affected and modified by anthropogenic factors (see also Martin-Díaz et al. 2020). 


\section{Food web interconnection and hierarchy}

Beginning in the early-middle Holocene, 'domestic ungulates became a major food source for vultures and other carrion eaters in many regions' (Moleón et al. 2014, 397). Intensification of herd management and domestic animal consumption in territories of early south Eurasian demographic concentration would have dramatically increased the supply of carcasses, providing an 'anthropogenic subsidy' to the primary scavengers and thereby deeply altering their specific ecological niches and thus the entire complex of interactions between humans and the other local species of big cats, raptors, hyenas, wild canids and secondary scavengers. In more arid peripheral landscapes, domesticated animals would have suffered a higher death rate due to climatic crises, malnutrition and related diseases, ${ }^{9}$ with different effects compared to those in other areas.

Among humans of the Bronze Age, as today, it would be the shepherds and communities of specialized herders that would be the direct witnesses of the important role of the primary scavengers (Morales-Reyes et al. 2019). As stated by McMahon $(2016,180,181)$,

Against the spread of humans and the sprawl of cities, animals are usually the losers. But vultures uniquely may have welcomed and thrived on the spread of humans and the expansion of cities, with their increased volume of organic rubbish, especially discard of dead draught animals and unused post-butchery carcass elements... The visual image of their associations with dead animals may have both reflected and invoked a mental image of the high value of their services.

As we have seen, however, vultures are and were not the only scavengers, and the same patterns likely held true for lions, hyenas and other smaller carnivore-scavengers. Animal deaths and the ensuing disposal patterns would have triggered foci of dynamic transformation involving multiple ecological actors, beginning with intense competition among vertebrate competitors for the nutrients in carrion and descending through the food chain of the invertebrates, microbial agents and finally the in situ vegetation. Vertebrate scavengers could also consume the lower-level invertebrates and microbes present in carrion; however, the ecological relations involving carrion should not be viewed as strictly hierarchical, since the transformations in populations and roles of a species would extend into the general ecosystem in a myriad of ways (Devault et. al. 2016).
No wonder, then, that the development of complex villages and then early urban societies was also a period in which 'spiritual, religious, and aesthetic values inspired by scavengers flourished worldwide' (Moléon et al. 2014, 397; see McMahon 2009; 2016), to the extent that, in a particular ecological community, 'The decline of vultures ... could lead to the loss of these ancient cultural and spiritual services' (Devault et al. 2016, 246).

According to Steinbeiser et al. (2018, 30), 'The presence of scavengers and the occurrence of predator effects could be intertwined ... vertebrate scavengers maintain their roles as predators even while engaged in the search for carrion. From the perspective of prey species near a carcass, an influx of scavengers could therefore enhance predation'. In short, the death of a larger animal triggers the temporary presence of a highly competitive trophic chain, with tangled sequences of access to the meat (Beasley et al. 2015, 111-13). Today, in Africa, the dominant scavengers are lions, hyenas and vultures, which consume nearly 50 per cent of small carcasses and nearly 100 per cent for medium and large ones. Vultures are obligate scavengers, able to take very little live prey, while hyenas and lions are opportunistic predator-scavengers. All of these compete for access and dominance on carcasses within the framing context of the regional geography, with success then being further determined by seasonal climate, factors of microsite habitat such as the presence of trees, and even the time of day, all of which will favour differing group sizes of one species over the other (Beasley et al. 2015, 111).

Vultures, differently from lions and hyenas, are daylight scavengers. Their advantage over lions is the speed with which they sight carcasses from air, exploiting hot air currents not available at night. They thus have carrion encounter rates much higher than their terrestrial competitors, and are often the initial consumers of carcasses. Lions and hyenas, in fact, locate carcasses through the presence of columns of spiralling birds, and lions also learn about the locations from the sounds of hyenas. Vultures can also swallow and depart with carrion meat at impressive speed, having evolved highly acidic stomachs which allow them to digest even putrefied flesh without being affected in the slightest (Beasley et al. 2015; De Vault et al. 2016).

The striped hyena may in some cases attack larger animals, including the young of domestic species, but mainly feed upon carcasses. After diurnal rest in underground burrows or caves, they begin solo trips in search of food in the early hours of darkness. Although their sight is relatively poor, they have 
the advantage of being able to scent a rotting carcass from a distance of $4 \mathrm{~km}$ and, compared to other carnivores, can cover great distances rapidly and without fatigue. Relying on their strong forelegs, they can dig out carrion cached by other animals (Habibi 2004, 67). Lions, and particularly hyenas, have anatomy suited to opening thick bones for access to their nutrient contents. Bearded vultures can do the same by dropping the bones from height onto rocks (Kane et al. 2017, 327-31).

Smaller carcasses are more difficult to spot by dominant scavengers and are mainly exploited by small-sized carnivores like mongooses and genets (Moleón \& Sánchez-Zapata 2015, 1007).

Once the carnivore-scavengers are present at the scene of larger carcasses, success in interspecies competition depends on group size, body size and aggressivity. Vultures, although often numerous, are necessarily respectful of the large carnivores, and obliged to stand aside. The striped hyena, if isolated or few in number, will submit to the apex predator, generally the lion, and indeed 'lions can acquire much of their carrion through kleptoparasitism of hyena kills' (Kane et al. 2017, 329). ${ }^{10}$ Hyenas are also known to submit even to cheetahs, leopards and caracal cats (Wagner et al. 2008). In the case of sufficient numbers of hyenas, however, they can abandon the usual safe distance and outcompete the apex predator for the carcass (Howard 1999). In Africa, although lions may fairly often kill hyenas, hyenas can also kill young lions. Eventually, no matter how thorough the work of the big cats at the scavenging sites, the hyena will still find food in what is left (Pereira et. al. 2014).

To sum up, obliged as we are to refer to African scenarios, a reconstructed hierarchy of interacting scavengers on the Iranian Plateau of the third millennium BC would have lions at the top, followed by other big cats (leopards, cheetahs), then striped hyenas, and finally large raptors (including bearded vultures). This is precisely the same threefold hierarchy expressed through the size and spacing of the iconographic elements on our chlorite vessel: the imposing lion in centre, hyenas nearby, raptors (readily understood as vultures) aside or in the background.

\section{Conclusions}

The scope of this work does not allow probing discussion of animal symbolism throughout the cities of the Near East and Middle Asia in the third millennium BC. In a cursory review of the coeval iconography of elite burials in Mesopotamia, however, we see rows of bovines, sheep and goats, illustrating wealth and the protective role of temples. Here, carnivores attack herbivores, while vultures feed on dead enemies-presumably legitimating aggressive and revengeful violence. On the well-known door plaques of Early Dynastic times, as well as in the central frieze of the 'standard' of the Royal Cemetery of Ur, sheep, goats and bulls quietly proceed to slaughter for ceremonial banqueting, while the draught animals that truly served in funerals were buried in the shafts of the tombs. More interestingly, from the same royal cemetery, on various forms of harps made or adorned with metals, we find different kinds of cloven-hoofed animals, perhaps hinting at the different sound of the instruments. On these, the ungulates and other animals, along with hybrid creatures, seem to work, play and sing like humans, almost mocking them. ${ }^{11}$ In all these instances, however, all the animals are depicted as food to be consumed or in other messages of elementary socio-political propaganda, at the most with reference to immaterial or mythical functions that have thus far been very difficult to interpret.

The scene on the new Jiroft vessel is completely different: here, in a 'materiality with its own independent characteristics' (Smart 2014, 4), we see the clear portrayal of four different animal species in dynamic interaction, composing the large part of a very realistic food web. The role of humans is indirectly communicated by the setting of these interactions in a liminal location, presumably the grounds between the irrigated lands and date-palm groves ringing the city and the more natural environment beyond, meaning the intermediate zone commonly used for dumping carcasses and known as the haunt of the nearest predator-scavengers. Both the dates and the flesh of bovids are food sources provided by domesticated species, offering a metaphor of nourishment ideally radiating from settlement into the wild outer landscapes-an effective praise for the 'civilizing' action of early states.

Recent studies have increasingly stressed the ecological importance of the scavenging animals and their roles in structuring and stabilizing trophic systems (Kane et al. 2017, 324; Moleón \& Sánchez-Zapata 2015). Moreover, 'Appreciation of the ecosystem services provided by scavengers to humanity is emerging only as vertebrate scavenger populations are more at risk than ever. Currently, vultures and opportunistic scavengers among large mammalian carnivores are widely missing or threatened around the globe' (Moléon et al. 2014, 394).

This new Halil Rud chlorite vessel shows an exceptionally early interest in the ecological and interspecies entanglement between predators, 
obligate and opportunistic scavengers, domestic animal and vegetal species and their associated human populations. Moreover, the carcass, and by extension its further decomposition processes, implicitly introduces insects and microbial processes to the iconographic conception: another important shift from the narrowest anthropocentric concerns (Boyd 2017, 300).

The images thus illustrate a highly transformative discourse, in which human observation of their animal commensals, as they adapted to the dramatically modified environments of the fourth and third millennia $\mathrm{BC}$, supported new templates and the creation of new social identities. What mattered were not the animals per se, but the relationships among the four species depicted, as well as the others only suggested. The elite of a people who regularly observed these inter-species relationships could gain cognitive inspiration and symbolic activation, from which they could then generate a powerful narrative: from the codification of the eco-systemic relationships in trophic chains at the city limits to the activation of powerful relational frameworks within the urbanizing society.

The scenes carved on this new vase and on others reported from the same cultural milieu set out a hierarchy of visual prominence that also conveys the interrelations of food access. In our case, in a single temporal sequence, the hierarchy relates lions, hyenas, vultures and bovines. Is this hierarchy a metaphor of a precisely stratified social interrelation of control over resources?

In a 'palaeo-Durkheimian' but also structuralist perspective, we propose an analogy between the ecologically stabilizing effects of hierarchical scavenging in the food web, itself undergoing dramatic modification, and the mutual entanglement of social roles and ranked functions in a rapidly changing society. Bearded vultures, as obligate scavengers necessarily contented with picking over bones, would symbolically represent the lowest social strata-naturally accepting the limitation of their resources to the residues left by the others. The strength of the cats, dominating the food chain, would support the right of the elites to the best of food resources and the mastery of lifestyles. At the same time, the setting of this newly observed 'scavenging hierarchy' in its liminal location-at the margins between urban and naturalpromotes a conception of order brought to natural existence and the value of the social order intrinsic to the newly forming state.

But we should avoid limitation to direct analogy of the structuralist type, since the Halil Rud chlorite cosmographic conceptions would evidently have been much vaster. The sensuous nature of the base material already suggests certain implications. Chlorite comes in different colours and shades, and whether plain, worked in patterns or figures, accepts an extraordinarily lustrous finish, both absorbing and reflecting light. The white colour of the powder from chlorite and steatite processing is similar to that of flour, while the yellowish-green, dark green to black colours of the finished products suggest the colours of many prepared foods. The ranges of brown stone, for example, echo the caramel and golden brown of the date halva that still features in Iranian funerary traditions. ${ }^{12}$

The visual space of the chlorite art would also serve simultaneously in other semantic systems, speaking for example of generation of food and peace, of struggle and death, of vivifying water, of worldly and supernatural actors and events:

where other modes of eating, growing, seeing, exchanging, cultivating, and hence, decomposing were being set in motion... Not only people but entire ecologiestrees, soils, plants, seeds, insects, microbes, and farmers-strive to collectively change the conditions of their lives... not by transcending these conditions, but rather by sinking into them, slowly turning them over, aerating, and breathing in new life that also potentiates different possibilities for and relations to death ... This is a death that decomposes into life, just as leaves spill from branch to ground, turn over and slowly rot to germinate from a pulsating layer ... again. (Lyons 2016, 59, 65, 76) ${ }^{13}$

\section{Notes}

1. 'No greater confusion exists than in the terminology of steatite, chlorite, and serpentine' (Lamberg-Karlovsky 1997, 89). The present document applies the term 'chlorite' in the conventional sense, signifying the soft stone used to carve the objects distinctive of the Halil Rud valley (or Marhašean, sensu Steinkeller 1982; 2012; 2013; 2014) tradition of the third millennium $\mathrm{BC}$. The range of stones quarried from various locations over the course of several centuries, and used in production of diverse styles, is so varied that three simple terms could not suffice for analytical classification. On the long discussion in this regard, see Kohl (1975; 1976; 1977; 1978; 1979; 2004; Kohl et al. (1979); Lamberg-Karlovsky (1997); Moorey (1999, 4651); D. Potts (1978; 1993); T. Potts 1989; 1994); more recently Francfort (2020) and Emami et al. (2017), in particular on recent efforts at characterizing chloritic rocks extracted and processed in the Halil Rud basin). Steinkeller (1982; 2012; 2013; 2014), D. Potts (1993) and Postgate (1997) discuss the possible terms for these stones in cuneiform script. Collon (2005) 
reviews the frequent mentions of steatite and chlorite as materials of Mesopotamian seals.

2. The fragmentary vessel of Mari, also very large, is reconstructed as a low truncated-conical form, with a slightly projecting flat rim, carved with a single frieze of intricate composition, with plants, goats and humans, in panels presumably separated by palms. The images of the five surviving fragments show the frieze bound above and below by bands of continuous spirals. If the friezes bounded by these guilloche bands were two, and not one as in the French reconstruction, the vessel would have been taller, and with its tapering contour, very similar to our specimen. Thus reconstructed, the dimensions of the Mari stone vessel (considering the height of two friezes in three bands) would be: base diameter 30.5 $\mathrm{cm}$; total height around $50 \mathrm{~cm}$. For other chlorite vessels fragments found at Mari, see Butterlin (2014).

3. On this unusual detail, see the section 'Techniques of execution'.

4. Besides the already quoted articles by Kohl, relying in part on the crucial discoveries from Tepe Yahya (Lamberg-Karlovsky 1970; 1988; 1993; Lamberg-Karlovsky \& Potts 2001), some of the most noted publications are: Aruz (2003); Aubet (2013); Cleuziou 2003; de Miroshedji (1973); Desset (2018); Hakemi (1997); Hejebri et al. (2012); Madjidzadeh (2003a); Marchesi (2016); Meier et al. (2016); Peyronel (2008); Piran \& Hesari (2005); Piran \& Madjidzadeh (2013); T. Potts (1989; 1994); Verderame (2019); Zarins (1978); Zettle \& Horne (1998).

5. A note on errors of identification in previous literature:

According to H.-P. Francfort 2020, n. 34): 'It is certain that the so called theme of the "fight between snakes and bearded eagle" is wrong, since the bird of prey is definitely a Gypaetus barbatus, the largest of vultures, never attacking a living being'; however, this assertion is in itself incorrect, since although its diet is largely dependent on scavenged carcasses, the bearded vulture also hunts small mammals, turtles and other reptiles (Margalida et al. 2009; Tenenzapf 2011).

According to Perrot and Madjidzadeh $(2005,144)$, the motif of the small raptor scavenger would be regularly accompanied by lions and 'lion cubs' near datepalms However, the sole example shown in this regard (Perrot \& Madjidzadeh 2005, fig. 7e) shows a lion facing three mastiff dogs, bearing collars inlaid with stones, without any trace of a lion cub. And our own Figure 3 shows at least two scavenging scenes where the raptor feeds on the carcass of sheep or goats, but then 'irregularly' lacks any association with lions and their prey.

6. For a different interpretation, see Vidale (2015).

7. Dogs appear on the Halil Rud chlorite art only as powerful mastiffs with collars, short floppy ears, and a thin tail terminating in a tuft, quite different from the furry tails of the creatures in discussion (Madjidzadeh 2003a, 57, 63, 64). As already stated, although Perrot and Madjidzadeh (2005; 2006) consider these depictions 'lion cubs', we find this interpretation not at all tenable.

8. See the flask at p. 94 of Madjidzadeh (2003a), also the handled weight at p. 126, perhaps with iconographic differences between young and adult bearded vultures. The inspiration for the game boards at pp. 130, 131 and 133 was clearly the bearded vulture, and not the generic 'eagle'.

9. See the disposal of butchered carcasses of sheep, goats and cattle on top of mass human graves at the periphery of Tell Brak in Syria, in the first half of the fourth millennium BC. In this case the human bones had also been exposed to animal scavenging before the final hasty burial (McMahon et al. 2011).

10. Kleptoparsitism: parasitic theft of the food of other species.

11. The various creatures appear as protomes and in the famous shell inlays of the harps. For detailed illustration see, for example, Aruz (2013, passim); Zettle \& Horne (1998). For specific discussion of the materiality and symbolism of the harps of PG 1237, Vidale (2011).

12. For the ingestion of the white powder of steatite and chloritic rocks in Sindh, based upon the faith in their supposed curative powers, see Shar \& Vidale (1991); for the hypothesis that chlorite containers with datepalm patterns contained halva, Vidale (2017).

13. We borrowed the subsequent quoted sentences from Lyons (2016), a work by a cultural anthropologist in a totally different geographic and cultural context. We also take the chance to disagree with a negative, depreciating discussion of chlorite pot BM 128887, a beautiful artwork that fully embodies the suggestions of the final quote (Perrot \& Madjidzadeh 2005, n. 36).

Massimo Vidale Department of Cultural Heritage Università degli Studi di Padova Complesso del Liviano Piazza Capitaniato 7 35139 Padova Italy $\mathcal{E}$ ISMEO, Rome Corso Vittorio Emanuele II, 244 Palazzo Baleani Roma RM 00186 Italy Email: massimo.vidale@unipd.it

Nasir Eskandari Department of Archaeology University of Tehran 16th Azar St Enghelab Sq. 
Tehran

Iran

Email:nasir.eskandari@ut.ac.ir (Corresponding Author)

Mojgan Shafiee

Lyon II University

Maison de l'Orient et de la Méditerranée - Jean Pouilloux

7 rue Raulin

69365 Lyon cedex 7

France

Email:shafie.mozhgan@yahoo.com

Irene Caldana

Department of Cultural Heritage

Università degli Studi di Padova

Complesso del Liviano

Piazza Capitaniato 7

35139 Padova

Italy

ISMEO, Rome

Corso Vittorio Emanuele II, 244

Palazzo Baleani

Roma RM 00186

Italy

Email: irene.caldana@gmail.com

Francois Desset

CNRS team Archéorient, Lyon

UMR 5133, France

Maison de l'Orient et de la Méditerranée - Jean Pouilloux

7 rue Raulin

69365 Lyon cedex 7

France

Email: francois.desset@wanadoo.fr

\section{References}

AbiSaid, M., \& S.M.D. Dloniak, 2015. Hyaena hyaena. The IUCN Red List of Threatened Species 2015: e. T10274A45195080. https://dx.doi.org/10.2305/ IUCN.UK.2015-2.RLTS.T10274A45195080.en (accessed 18 June 2020).

Amiet, P., 1986. L'âge des échanges inter-iraniens: 3500-1700 avant J.-C. [The age of the inter-Iranian exchanges: 3500-1700 BC]. Paris: Editions de la Réunion des Musées Nationaux.

Anderson, S., 2012. Hyena. Encyclopaedia Iranica 12(6), 600603. Available at: http://www.iranicaonline.org/ articles/hyena

Aruz, J., 2003. 'Intercultural Style' carved chlorite vessels, in Art of the First Cities, ed. J. Aruz. New Haven/ London: Metropolitan Museum of Art/Yale University Press, 325-45.
Aubet, M.E., 2013. Commerce and Colonization in the Ancient Near East. Cambridge: Cambridge University Press.

Beasley, J.C., Z.H. Olson \& Devault, T.L., 2015. Ecological role of vertebrate scavengers, in Carrion Ecology, Evolution, and their Applications, eds M.E. Benbow, J. K. Tomberlin \& A.M. Tarone. Boca Raton (FL): CRC Press, 107-27.

Bopanna, I.P., 2013. Habitat Use, Ranging Pattern and Food Habits of Striped Hyaena (Hyaena hyaena) in Kutch, Gujarat. PhD thesis, Saurashtra University.

Boyd, B., 2017. Archaeology and human-animal relations: thinking through anthropocentrism. Annual Review of Anthropology 46, 299-316.

Butterlin, P., 2014. Les vases en chlorite de temple d'Ishtar et le 'système-monde' sumérien [The chlorite vessels from the temple of Ishtar and the Sumerian 'worldsystem'], in Voués à Ishtar. Syrie, janvier 1934, André Parrot découvre Mari [Dedicated to Ishtar. Syria, January 1934, André Parrot discovers Mari], eds S. Cluzan \& P. Butterlin. Beirut: Presses de l'IFPO, 21-34.

Chen, S., B.-Z. Lin, M. Baig, et al., 2010. Zebu cattle are an exclusive legacy of the South Asia Neolithic. Molecular Biology and Evolution 27(1), 1-6.

Cleuziou, P.S., 2003. Jiroft et Tarut, in Jiroft fabuleuse découverte en Iran [Jiroft: fabulous discovery in Iran], eds J. Perrot \& Y. Madjidzadeh. (Dossiers d'Archéologie 287.) Paris: Éditions Faton, 114-25.

Collon, D., 2005. First Impressions. Cylinder seals in the ancient Near East. London: British Museum Publications.

de Miroschedji, P., 1973. Vases et objets en stéatite susiens $d u$ musée du Louvre [Susian chlorite vessels and objects of the Louvre Museum]. (Cahiers de la Délégation Archéologique Française en Iran 3). Paris: Association paléorient, 9-79.

Desset, F., 2018. Survey of the Relation Between the Halil Rud Culture Chlorite Artefacts and Their Decorative Pattern. Paper presented at the 2nd International Conference on the Archaeology of Southeastern Iran, Jiroft, 11-13 December 2017.

DeVault, T.L., J.C. Beasley, Z.H. Olson, M. Moleón, M. Carrete, A. Margalida, \& J.A. Sánchez-Zapata, 2016. Ecosystem services provided by avian scavengers, in Why Birds Matter: Avian ecological function and ecosystem services, eds C.H. Şekercioğlu, D. G. Wenny \& C.J. Whelan. Chicago (IL): University of Chicago Press, 235-70.

Emami, M., M. Razanib, N. Alidadi Soleimani \& Y. Madjidzadeh, 2017. New insights into the characterization and provenance of chlorite objects from the Jiroft civilization in Iran. Journal of Archaeological Science: Reports 16, 194-204.

Francfort, H.-P., 2020. The Grand Route of Khorasan (Great Khorasan Road) during the third millennium BC and the 'dark stone' artefacts, in The Iranian Plateau during the Bronze Age: Development of urbanisation, production and trade, eds J.-W. Meyer, E. Vila, M. Mashkour, M. Casanova \& R. Vallet. Lyon: MOM Éditions, 247-66. 
Frembgen, J.W., 1998. The magicality of the hyena: beliefs and practices in west and south Asia. Asian Folklore Studies 57(2), 331-44.

Habibi, K., 2004. Mammals of Afghanistan, Kabul: Wildlife Conservation Society.

Hakemi, A., 1997. Kerman: the original place of production of chlorite stone objects in the 3rd millennium B.C. East and West 47(1-4), 11-40.

Hejebri Nobari, A., H. Basafa, H. Khatib Shahidi \& J. Neyestani, 2012. A comparative sudy of chlorite vessels iconography, discovered from Halil Rud Basin. Archives des Sciences 65(1), 2-11.

Hess, C.W., \& Streck, M.P., 2009. File Name: Etana, Trasliteration, Translation, Commentary, 23.3.2009. www.seal.uni-leipzig.de/data/epics/Etana.pdf (accessed 15 September 2010).

Hole, F., \& C. Wyllie, 2007. The oldest depictions of canines and a possible early breed of dog in Iran. Paléorient 33(1), 175-85.

Howard, C., 1999. Hyaena hyaena. Animal Diversity Web. https://animaldiversity.org/accounts / Hyaena_hyaena/ (accessed 21 June 2020).

Kane, A., K. Healy, T. Guillerme, G.D. Ruxton \& A. L. Jackson, 2017. A recipe for scavenging in vertebrates - the natural history of a behaviour. Ecography 40, 324-34.

Karimov, T., \& C. Guliyev, 2017. Diet composition of four vulture species in Azerbaijan. Ardea 105(2), 163-8.

Kinnier Wilson, J.V., 1985. The Legend of Etana: A new edition. Warminster: Aris \& Phillips.

Kitchener, A.C., C. Breitenmoser-Würsten, E. Eizirik, A. Gentry, L. Werdelin, A. Wilting \& N. Yamaguchi, 2017. A revised taxonomy of the Felidae. The final report of the Cat Classification Task Force of the IUCN/SSC Cat Specialist Group. CATnews Special Issue 11.

Kohl, P., 1975. Carved chlorite vessels: a trade in finished commodities in the mid-third millennium. Expedition 18(1), 18-31.

Kohl, P., 1976. 'Steatite' carvings of the early third millennium B.C. American Journal of Archaeology 80(1), 73-5.

Kohl, P., 1977. A note on chlorite artefacts from Shahr-i Sokhta. East and West 27(1-4), 111-27.

Kohl, P., 1978. The balance of trade in southwestern Asia in the mid-third millennium B.C. Current Anthropology 19, 463-92.

Kohl, P., 1979. The 'world economy' of west Asia in the third millennium B.C., in South Asian Archaeology 1977, ed. M. Taddei. Naples: Istituto Universitario Orientale, 55-86.

Kohl, P., 2004. Chlorite and other stone vessels and their exchange on the Iranian plateau and beyond, in Persiens Antike Pracht: Katalog der Ausstellung des Deutschen Bergbau-Museum Bochum [Persia's ancient splendour: catalogue of the exhibition of the German Mining Museum Bochum], eds T. Stöllner, R. Slotta \& A. Vatandoust. Bochum: Deutsches Bergbau -Museum, Vol. 1, 282-89.
Kohl, P.C., G. Harbottle \& E.V. Sayre, 1979. Physical and chemical analyses of soft stone vessels from southwest Asia. Archaeometry 21, 131-59.

Lamberg-Karlovsky, C.C., 1970. Excavations at Tepe Yahya, Iran, 1967-1969, Progress Report I. (American School of Prehistoric Research Bulletin 27). Cambridge (MA): Peabody Museum of Archaeology and Ethnology, Harvard University.

Lamberg-Karlovsky, C.C., 1988. The Intercultural Style carved vessels. Iranica Antiqua 23, 45-95.

Lamberg-Karlovsky, C.C., 1993. The biography of an object: the intercultural vessels of the third millennium B.C., in History from Things: Essays on material culture, eds. S. Lubar \& W.D. Kingery. Washington (DC): Smithsonian Institution Press, 270-92.

Lamberg-Karlovsky C.C., 1997. Our past matters: materials and industries of the ancient Near East. Ancient Mesopotamian Materials and Industries: The Archaeological Evidence, by P.R.S. Moorey. Review. Journal of the American Oriental Society 117(1), 87-102.

Lamberg-Karlovsky C.C. \& D.T. Potts, 2001. Excavations at Tepe Yahya, Iran, 1967-1975. Vol. III: The third millennium. (American School of Prehistoric Research Bulletin 45.) Cambridge (MA): Peabody Museum of Archaeology and Ethnology, Harvard University.

Lambert, G., 1965. A new look at the Babylonian background of Genesis. Journal of Theological Studies 16, 287-300.

Lambert, W.G. \& A.R. Millard, 1969. Atra-Hasīs: The Babylonian Story of the Flood. With The Sumerian Flood Story by M. Civil. Oxford: Clarendon Press.

Lyons, K., 2016. Decomposition as life politics: soils, selva, and small farmers under the gun of the $U$. S.-Colombian war on drugs. Cultural Anthropology 31(1), 56-81.

Madjidzadeh, Y., 2003a. Jiroft: The earliest oriental civilization. Tehran: Ministry of Culture and Islamic Guidance.

Madjdzadeh, Y., 2003b, (ed.) Jiroft: Fabuleuse découverte en Iran [Jiroft: A fabulous discovery in Iran]. (Dossiers d'Archéologie 287) Paris: Éditions Faton.

Madjidzadeh, Y., 2007. Presentation of the Archaeological Excavations at Jiroft: Halil Roud Basin, Kerman (20032007). ICAR/ICHTO, Tehran.

Marchesi, G., 2016. Object, images, and text: remarks on two 'Intercultural Style' vessels from Nippur, in Materiality of Writing in Early Mesopotamia, eds. T. E. Balke \& C. Tsouparopoulou. Berlin/Boston: Walter de Gruyter, 102.

Margalida, A., J. Bertran \& R. Heredia, 2009. Diet and food preferences of the endangered Bearded Vulture Gypaetus barbatus: a basis for their conservation. Ibis 151, 235-43.

Margueron, J.-Cl., 2004. Mari. Métropole de l'Euphrate au début du II Millénaire av. J.-C. [Mari. A metropolis of the Euphrates at the beginning of the 2nd millennium BC]. Paris: Picard/erc.

Martin-Díaz, P., A. Cortés-Avizanda, D. Serrano, E. Arrondo, J.A. Sánchez-Zapata \& J.A. Donázar, 
2020. Rewilding processes shape the use of Mediterranean landscapes by an avian top scavenger. Scientific Reports 10, 2853. https://doi.org/10. 1038/s41598-020-59591-2

McMahon, A., 2009. The lion, the king and the cage: Late Chalcolithic iconography and ideology in northern Mesopotamia. Iraq 71, 115-24.

McMahon, A., 2016. The encultured vulture: Late Chalcolithic sealing images and the challenges of urbanism in 4th millennium northern Mesopotamia. Paléorient 42(1), 169-83.

McMahon, A., A. Sołtysiak \& J. Weber, 2011. Late Chalcolithic mass graves at Tell Brak, Syria, and violent conflict during the growth of early city-states. Journal of Field Archaeology 36(3), 201-20.

Meier, D.M.P., D. Yaşin Meier \& S. Piran, 2016. Ritzverzierte Chloritgefäße (Ost)Iranischer Provenienz aus der Sammlung des Museums für Vor- und Frühgeschichte [Incised chlorite vessels of (east) Iranian provenance from the collection of the Museum of Prehistory and Early History]. Acta Praehistorica et Archaeologica 48, 1-17.

Mohammadi, A., M. Kaboli, V. Sazatornil \& J. V. Lopéz-Bao, 2019. Anthropogenic food resources sustain wolves in conflict scenarios of western Iran. PLoS ONE 14(6), e0218345.

Moleón, M. \& J.A. Sánchez-Zapata, 2015. The living dead: time to integrate scavenging into ecological teaching. BioScience 65, 1003-10.

Moleón M., J.A. Sánchez-Zapata, A. Margalida, M. Carrete, N. Owen-Smith \& J.A. Donázar, J.A., 2014. Humans and scavengers: the evolution of interactions and ecosystem services. BioScience 64(5), 394-403.

Monchot, H. \&. M. Mashkour, 2010. Hyenas around the city (Kashan, Iran). Journal of Taphonomy 8(1), 17-32.

Moorey, P.R.S., 1999. Ancient Mesopotamian Materials and Industries: The archaeological evidence. Winona Lake (IN): Eisenbrauns.

Morales-Reyes, Z., B. Martín-López, M. Moleón, et al., 2019. Shepherds' local knowledge and scientific data on the scavenging ecosystem service: insights for conservation. Ambio 48, 48-60.

Muscarella, O.W., 1993. Intercultural style 'weights'. Bulletin of the Asia Institute (n.s.) 7, Iranian Studies in Honor of A.D.H. Bivar, 143-53.

Nowell, K. \& P. Jackson (eds), 1996. Wild Cats. Status Survey and Conservation Plan. Gland: IUCN.

Omidsalar, M., \& T. Omidsalar, 2012. Fox ii. In Persia. Encyclopaedia Iranica 10(2), 120. Available at: http:// www.iranicaonline.org/articles/fox-2

Pereira, L.M., N. Owen-Smith \& M. Moleón, 2014. Facultative predation and scavenging by mammalian carnivores: seasonal, regional and intra-guild comparisons. Mammal Review 44, 44-55.

Perrot, J. \& Y. Madjidzadeh, 2005. L'Iconographie des vases et objects en chlorite de Jiroft, Iran [The iconography of vessels and objects in chlorite of Jiroft, Iran]. Paléorient 31(2), 123-57.
Perrot, J. \& Madjidzadeh, Y., 2006. A travers l'ornementation des vases et objets en chlorite de Jiroft [The ornamentation of vessels and objects in chlorite of Jiroft]. Paléorient 32(1), 99-112.

Peyronel, L., 2008. Storia e Archeologia del Commercio nell'Oriente Antico [History and archaeology of trade in the ancient east]. Rome: Carocci.

Piran, S. \& M. Hesari, M., 2005. Cultural around Halil Roud and Jiroft. The catalogue of exhibition of select restituted objects. Tehran: National Museum of Iran.

Piran, S. \& Y. Madjidzadeh, 2013. Objects from the Jiroft Treasury, Soft Stone and Alabaster Objects (Recovered Collection) from the Halil River Basin. Tehran: National Museum of Iran.

Pittman, H., 1990. Steatite or chlorite handled weight, in Glories of the Past: Ancient art from the Shelby White and Leon Levy Collection, ed D. von Bothmer. New York (NY): Metropolitan Museum of Art, 41-3.

Pocock, R.I., 1939. The Fauna of British India, Including Ceylon and Burma. Mammalia. Vol. I. Primates and Carnivora (in part), Families Felidae and Viverridae. London: Taylor \& Francis.

Postgate, N., 1997. Mesopotamian petrology: stages in the classification of the material world. Cambridge Archaeological Journal 7(2), 205-24.

Potts, D., 1978. Comment on P. Kohl, 'The balance of trade in southwestern Asia in the mid-third millennium B. C.' [and comments and reply]. Current Anthropology 19(3), 463-92.

Potts, D., 1993. Soft stone from Oman and Eastern Iran in cuneiform sources. Res Orientales 5, 9-13.

Potts, T., 1989. Foreign stone vessels of the late third millennium B.C. from southern Mesopotamia: their origins and mechanisms of exchange. Iraq 51,123-64.

Potts, T. 1994. Mesopotamia and the East. An archaeological and historical study of foreign relations ca. 3400-2000 $B C$. Oxford: Oxford University Committee for Archaeology.

Ryan, K. \& P.J. Crabtree, 1995. The Symbolic Role of Animals in Archaeology. Philadelphia (PA): University of Pennsylvania Press/University of Pennsylvania Museum of Archaeology and Anthropology.

Serjeantson, D., 2000. Good to eat and good to think with: classifying animals from complex sites, in Animal Bones, Human Societies, ed P. Rowley-Conwy. Oxford: Oxbow, 179-89.

Shamshad Alam, M., J. Akhtar Khan \& B. Pathak, 2015. Striped hyena (Hyaena hyaena) status and factors affecting its distribution in the Gir National Park and Sanctuary, India. Folia Zoologica 64, 32-9.

Shar, G.M. \& M. Vidale, 1991. Zahar Muhrow: soapstonecutting in contemporary Baluchistan and Sind. Annali dell' Istituto Universitario Orientale di Napoli 50(1), 61-78, pls. I-XII.

Smart, A., 2014. Critical perspectives on multispecies ethnography. Critique of Anthropology 34(1), 3-7.

Steinbeiser, C.M., C.A. Wawrzynowski, X. Ramos \& Z. $\mathrm{H}$. Olson, 2018. Scavenging and the ecology of fear: 
do animal carcasses create islands of risk on the landscape? Canadian Journal of Zoology 96, 229-36.

Steinkeller, P., 1982. The question of Marhaši: a contribution to the historical geography of Iran in the third millennium B.C. Zeitschrift für Assyriologie 72, 237-65.

Steinkeller, P., 2012. New light on Marhaši and its contacts with Makkan and Babylonia, in Aux marges de l'archéologie. Hommage à Serge Cleuziou [On the margins of archaeology: in honour of Serge Cleuziou], eds J. Giraud \& G. Gernez. (Travaux de la Maison René-Ginouvès 16.) Paris: de Boccard, 261-74.

Steinkeller, P., 2013. Trade routes and commercial networks in the Persian Gulf during the third millennium BC, in Collection of Papers Presented to the Third International Biennial Conference of the Persian Gulf (History, Culture, and Civilization), ed. C. Faizee. Tehran: Scientific Board of the Third International Conference of the Persian Gulf, Department of History, University of Tehran, 413-31.

Steinkeller, P., 2014. Marhaši and beyond: the Jiroft civilization in a historical perspective, in My Life is Like a Summer Rose. Maurizio Tosi e l'Archeologia come modo di vivere. Papers in honour of Maurizio Tosi for his 70th birthday, eds C.C. Lamberg-Karlovsky, B. Genito \& B. Cerasetti. (BAR International series S2690). Oxford: BAR Publishing, 691-707.

Tenenzapf, J., 2011. Gypaetus barbatus. Animal Diversity Web. https://animaldiversity.org/accounts/ Gypaetus_barbatus/ (accessed 25 June 2020).

Verderame, L., 2019. Text, context, and the social dimension of writing: a case study from the early Dynastic Inanna temple at Nippur. In Ancient Near Eastern Temple Inventories in the Third and Second Millennia BCE: Integrating archaeological, textual, and visual sources, eds J.M. Evans \& S. Roßberger. (Proceedings of a conference held at the LMU Centre for Advanced Studies, November 14-15, 2016.) Gladbeck: PeWe-Verlag, 27-44.

Vidale, M., 2011. PG 1237, Royal Cemetery of Ur: Patterns in Death. Cambridge Archaeological Journal 21(3), 427-51.

Vidale, M., 2015. Searching for mythological themes on the 'Jiroft' chlorite artefacts. Iranica Antiqua 50, 15-58.

Vidale, M., 2017. Protohistory of the vara. Exploring the Proto-Indo-Iranian background of an early mytheme of the Iranian Plateau. Journal of Indo-European Studies 45(1 \& 2), 1-31.

Wagner, A.P., L.G. Frank \& S. Creel, 2008. Spatial grouping in behaviourally solitary striped hyaenas, Hyaena hyaena. Animal Behaviour 75(3), 1131-42.

Wilson, K., 2012. Bismaya. Recovering the lost city of Adab. Chicago (IL): Oriental Institute.

Winkelmann, S., 2005. Deciphering the Intercultural Style?, in South Asian Archaeology 2003, eds U. Franke Vogt \& H.J. Weisshaar. Bonn: Linden Soft, 185-98.
Zarins, J., 1978. Typological study in Saudi Arabian archaeology. Steatite vessels in the Riyadh Museum. Atlal 2, 65-93.

Zettle, R.L. \& L. Horne, 1998. Treasures from the Royal Tombs of Ur. Philadelphia (PA): University of Pennsylvania Museum of Archaeology and Anthropology.

\section{Author biographies}

Massimo Vidale is Associate Professor at the Department of Cultural Heritage of the University of Padova (Italy), where he teaches Bronze Age Archaeology of Central Asia, Iran and the Indus valley. For ISMEO, he directs the Italian Archaeological Mission to Southeastern Iran. His main research interests include the reconstruction of ancient technologies and trade patterns in the broader context of the formation of early states in protohistoric Middle and South Asia.

Nasir Eskadari is an assistant professor of archaeology at the University of Tehran. He is currently head of the Research Center for Archaeology of Jiroft, ICHTM. He has conducted fieldwork in different regions of the Iranian Plateau, mostly in southeastern Iran. He has directed excavations at sites of Shahdad, Konar Sandal and Varmin-e Jiroft. His current field research is focused on the Jiroft plain from the Chalcolithic period to the Iron Age.

Mojgan Shafiee is a $\mathrm{PhD}$ candidate in the University of Lumière Lyon 2. She has been envolved in the prehistoric archaeology of southeastern Iran since 2011. She has been a member of many archaeological excavations and surveys in the region. Her current field of study is focused on the Chalcolithic of southeastern Iran.

Irene Caldana is a graduate of the University of Padua, and a member of the Italian Archaeological Mission to southeastern Iran. She has worked both in the field of Italian protohistory and in South Asia, through iconographic studies and applying experimental archaeology to the reconstruction of ancient technologies. She is currently studying the protohistoric ceramic sequences of the Swat Valley, Pakistan.

Francois Desset works on the archaeology of Bronze Age Iran (4000-1500 BC). He takes part in archaeological activities in the Halil Rud valley (Jiroft) and other archaeological regions of the Iranian Plateau. For more than 10 years he has been involved in the study of Iranian undeciphered writing systems, collaborating with other experts and philologists from different countries. 